\title{
Iodine Toxic to Young Animals
}

\author{
by M. Akerib,
}

\author{
Laboratory of Drug Metabolism, School of Medicine, \\ University of Geneva, Switzerland
}

$\mathrm{D}$

URING the past few years, some laboratories have become interested in extrathyroidal iodine metabolism. However, little is still known on the subject.

The nutritionists, on the other hand, are increasingly interested in the control that the thyroid gland seems to exert on growth, and the part played by iodine in this process.

Creek et al (8) find the requirements in iodine for an optimal growth of the chick to be of $75 \mathrm{ppb}$. However, in amounts less than $300 \mathrm{ppb}$, they noticed hypertrophies and hyperplasies. These symptoms were corrected with amounts reaching $300-400 \mathrm{ppb}$. They found no significant differences in the needs of different breeds of chicks.

In a study carried out by Akerib and Paquin (1), the authors found that 2,500 ppm given to 7-day old chicks caused, after 21 days, a 30 per cent growth inhibition. Those chicks receiving $5,000 \mathrm{ppm}$ showed an 80 per cent growth inhibition and a mortality reaching 75 per cent.

Other authors have also found iodine to be toxic to young chicks, and to young animals of other species as well.

Perdomo et al (13) found that in laying hens receiving a supplement of KI, laying diminishes or stops altogether according to the dose, the highest being 5,000 ppm. Egg fertility is not altered, but $\mathrm{KI}$ supplementation causes the early death of the embryos, and a retarded hatching with a diminished rate. This experiment lasted for 28 days.

Arrington (4) duplicated this experiment and observed the same results. At two weeks of age, the chicks hatched from control hens weighed $88.5 \mathrm{~g}$, and those hatched from hens receiving $2,500 \mathrm{ppm}$ weighed $68.7 \mathrm{~g}$.

Mayberry and Hockert (11) working with White Leghorn, Rhode Island Red, White Rock, and Viking Meat Bird chicks, gave them from the first day of their life, different doses of KI dissolved in drinking water. They noticed a growth inhibition, and that an excess of iodine does not cause a blocking of $\mathrm{I}^{131}$ absorption.

One should, however, note that the amount of consumed water was not calculated. Indeed, animals receiving supplemented water 
may not consume as much of it as the control animals. This might explain the fact that no pathological condition was observed.

Wolff et al (15) gave intraperitoneal injections to some rats every eight hours during one to four weeks. The injections contain 500, 1,000 or $2,000 \mathrm{~g}$ of $\mathrm{I}^{127}$ in the form of $\mathrm{KI}$ in a saline solution of 0.9 per cent. The authors found an inhibition of organic iodine formation, this being aggravated by a nephrectomy. The inhibition was, however, only temporary.

Correa and Welsh (7) fed male rats with a diet containing $0.796 \mathrm{~g}$ KI per $100 \mathrm{~g}$ of food. The animals had thus an intake of $0.119 \mathrm{~g}$ $\mathrm{KI} /$ day. The animals were found to have enlarged, mostly resting, colloid-rich glands and a low uptake of $\mathrm{I}^{131}$.

Arrington et al (3) fed pregnant female rats with iodine supplements ranging from 0 to $2,500 \mathrm{ppm}$. They found a high rate of postnatal mortality, this rate increasing proportionally to the dose of iodine given to the mother. Lactation was severely diminished or completely stopped.

Arrington et al (5) show that doses of 250 to $1,000 \mathrm{ppm}$ iodine given from two to five days to pregnant female rabbits caused a high rate of mortality in the new-born. The hamsters were not affected by doses of $2,500 \mathrm{ppm}$, showing only a diminished feed intake. The young weighed less at weaning. The rats showed a prolonged parturition. Swine were unaffected by high doses of iodine. Both rats and rabbits, after being taken off the supplemented feeds, produced normal litters.

Although no one has, to date, attempted to determine the physiological and biochemical basis of this toxicity, one can find some clues in the literature and, taking them as a basis, speculate.

Ullberg and Ewaldsson (14) using autoradiographic techniques show, in pregnant mice, rats and cats, an $I^{131}$ concentration in the foetus in the choroid plexus, the arterial walls, tendons, cornea and sclerotica and in the thymus. The iodine activity in foetal tissues was superior to that found in maternal tissues after a latent period of about 20 minutes. In the fully developed foetus, the $I^{131}$ was also localised in the thyroid, the stomach and the salivary glands, but not in the same proportions as in the mother. All the foetuses accumulated a greater activity in the thymus than in the other tissues. In the adult animals the accumulation in the thymus was only evident in a few pregnant mice.

An activity greater in foetal tissues than in maternal tissues was already shown by Logothetopoulos and Scott (10).

However, Brown-Grant (6) is of the opinion that this might only be so for those species with a hemochorial or hemoendothelial placenta. One can therefore put forward two hypotheses:

(a) the sensibility of foetuses and new-born animals to iodine is due to their greater power of concentration of this element in their tissues; 
(b) iodine accumulation in the thymus is the cause of this sensibility. However, Michel et al (12) find that metallic iodine and CNI are inhibitors of xanthine oxydase, in vitro.

Xanthine oxydase oxydises xanthine into uric acid. This is excreted by primates, some reptiles and a few insects as the final product of purine catabolism, and is excreted by birds as the final product of protein, purine and pyrimidine catabolism (2).

Could the inhibition of this enzyme be the cause, or at any rate, one of the causes of iodine toxicity, even though Michel et al (12) find $\mathrm{KI}$ to have no inhibiting effect?

Henon (9), on the other hand, finds that the $\propto$-glycerophosphate oxydase activity in rat hepatic mitochondria is thyroxine dependent. The activity of this enzyme increases after birth, but decreases again after weaning. Could this enzyme be inhibited by high doses of iodine?

All these different experimental results lead us to a great number of questions. It is now time to seek the answers.

Resumé

\section{TOXICITE DE L'IODE POUR LES JEUNES ANIMAUX}

\section{AKERIB}

La plupart des comptes-rendus de recherche révèlent qu'une teneur en iode supérieure à $5,000 \mathrm{ppm}$ peut être toxique pour les jeunes poussins et provoquer chez la Poule une diminution de la production d'oeufs, du développement embryonnaire et de la croissance initiale des poussins. On a observé des résultats similaires chez le Rat.

L'auteur suggère que les foetus et les très jeunes animaux doivent concentrer davantage l'iod dans leurs tissus et qu'une accumulation d'iode dans le thymus pourrait être la cause de la sensibilité décrite ci-dessus. Il se demande si l'inhibition de la xanthine oxydase ou de l' $\propto$-glycérophosphate oxydase pourrait être impliquée, chez le jeune animal, dans l'apparition des phénomènes de toxicité liés à une importante ingestion d'iode.

\section{REFERENCES}

1. AKERIB, M., J. PAQUIN. Unpublished results.

2. ALTMAN, P. L., D. S. DITTMER. (1968). Metabolism. Federation of American Societies for Experimental Biology. p.p 429-430.

3. AMMERMAN, C. B., L. R. ARRINGTON, A. C. WARWICK, J. L. EDWARDS, R. L. SHIRLEY, G. K. DAVIS. (1964). J. Nutrition 84, 2, 107-112.

4. ARRINGTON, L. R. (1967). J. Nutrition 92, 325-330.

5. ARRINGTON, L. R., R. N. TAYLOR, Jr., C. B. AMMERMAN, R. L. SHIRLEY. (1965). J. Nutrition 87, 4, 394-398.

6. BROWN-GRANT, K. (1961). Physiological Rev. 41, 1, 189.

7. CORREA, P., R. A. WELSH. (1960). Arch Pathol. 70, 247-251.

8. CREEK, et al. (1957). Poultry Sci, 36, 6, 1360

9. HEMON, P. (1967). Biochim. Biophys. Acta. 132, 175.

10. LOGOTHETOPOULOS, J. H., R. F. SCOTT. (1955). Nature 175, 775.

11. MAYBERRY, W. E., T. J. HOCKERT. (1968). Proc. Soc. Exper. Biol. Med. 129, 370-373.

12. MICHEL, R., R. TRUCHOT, H. TRON-LOISEL, A.-M. QUIGNARD. (1967). Compt. rend. des sceances de la Societe de Biologie. 161, 7, 1512.

13. PERDOMO, J. T., L. R. ARRINGTON. (1966). Proc. Soc. Exp. Biol. Med. 122, 758-760.

14. ULLBERG, S., B. EWALDSSON. (1964). Acta Radiologica 2, 1, 24-32.

15. WOLFF, J., I. L. CHAIKOFF, R. C. GOLDBERG, J. R. MEIER. (1949). Endocrinology 34, 504 .

16. The author of this review is the 1969-70 Battelle Memorial Fellow in Biological Sciences. 